\title{
CaO INSULATOR COATINGS AND SELF-HEALING OF DEFECTS ON V-Cr-Ti ALLOYS IN LIQUID LITHIUM SYSTEM*
}

\author{
RECEIVED \\ J.-H. Park and T. F. Kassner \\ NOV 211995 \\ Energy Technology Division, Argonne National Laboratory \\ Argonne, Illinois 60439 \\ OSTI
}

September 1995

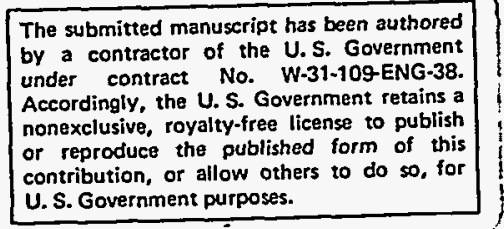

DISCLAIMER

This report was prepared as an account of work sponsored by an agency of the United States Government. Neither the United States Government nor any agency thereof, nor any of their employees, makes any warranty, express or implied, or assumes any legal liability or responsibility for the accuracy, completeness, or usefulness of any information, apparatus, product, or process disclosed, or represents that its use would not infringe privately owned rights. Reference herein to any specific commercial product, process, or service by trade name, trademark, manufacturer, or otherwise does not necessarily constitute or imply its endorsement, recommendation, or favoring by the United States Government or any agency thereof. The views and opinions of authors expressed herein do not necessarily state or reflect those of the United States Government or any agency thereof.

Submitted to Seventh International Conference on Fusion Reactor Materials (ICFRM-7), Obninsk, Russia, September 25-29, 1995.

\footnotetext{
"Work supported by the U.S. Department of Energy, Office of Fusion Energy Research, under Contract W-31109-Eng-38.

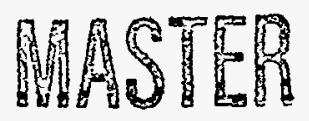




\section{DISCLAIMER}

\section{Portions of this document may be illegible electronic image products. Images are produced from the best available original document.}




\title{
CaO INSULATOR COATINGS AND SELF-HEALING OF DEFECTS ON V-Cr-Ti ALLOYS IN LIQUID LITHIUM*
}

\author{
J.-H. Park and T. F. Kassner \\ Energy Technology Division, Argonne National Laboratory
}

Argonne, Illinois 60439

\begin{abstract}
Electrically insulating and corrosion-resistant coatings are required at the liquid metal/structural interface in fusion first-wall/blanket applications. Electrical resistance of $\mathrm{CaO}$ coatings that were produced on $\mathrm{V}-5 \% \mathrm{Cr}-5 \% \mathrm{Ti}$ by exposure of the alloy to liquid $\mathrm{Li}$ containing 0.5-85 wt.\% dissolved $\mathrm{Ca}$ was measured as a function of time at temperatures between 250 and $600^{\circ} \mathrm{C}$. The solute element, $\mathrm{Ca}$ in liquid $\mathrm{Li}$, reacted with the alloy substrate at $400-420^{\circ} \mathrm{C}$ to produce a $\mathrm{CaO}$ coating. Resistance of the coating layer measured in-situ in liquid $\mathrm{Li}$ was $\approx 10^{6} \Omega$ at $400^{\circ} \mathrm{C}$. Thermal cycling between 300 and $700^{\circ} \mathrm{C}$ changed the coating layer resistance, which followed insulator behavior. These results suggest that thin homogeneous coatings can be produced on variously shaped surfaces by controlling the exposure time, temperature, and composition of the liquid metal. The technique can be applied to various shapes (e.g., inside/outside of tubes, complex geometrical shapes) because the coating is formed by liquid-phase reaction. Examination of the specimens after cooling to room temperature revealed no spallation, but homogeneous crazing cracks were present in the $\mathrm{CaO}$ coating. Additional tests to investigate the in-situ self-healing behavior of the cracks indicated that rapid healing occurred at $\geq 360^{\circ} \mathrm{C}$.
\end{abstract}

\section{INTRODUCTION}

Electrically insulating and corrosion-resistant coatings are required at the liquid-metal/structural interface in a magnetic fusion reactor to minimize the magnetohydrodynamic force and its influence on thermal hydraulics of liquidmetal cooling systems [1]. Vanadium and V-base alloys ( $\mathrm{V}-\mathrm{Ti}$ or $\mathrm{V}$-Ti-Cr) are leading candidate materials for structural applications in fusion reactors because

\footnotetext{
"Work supported by the U.S. Department of Energy, Office of Fusion Energy Research, under Contract W-31109-Eng-38.
} 
of their many benefits, including the capability to fabricate ceramic and intermetallic phases on the alloys in a liquid-metal environment [2-4]. In-situ formation of $\mathrm{CaO}$ on $\mathrm{V}-5 \mathrm{Cr}-5 \mathrm{Ti}$ in liquid $\mathrm{Li}$ was investigated because the electrical resistivity of $\mathrm{CaO}$ is very high and also because $\mathrm{CaO}$ exhibits a higher thermodynamic stability in liquid $\mathrm{Li}$ than do other potential insulator candidates $\left(\mathrm{Y}_{2} \mathrm{O}_{3}, \mathrm{BeO}, \mathrm{MgO}, \mathrm{MgAl}_{2} \mathrm{O}_{4}, \mathrm{Y}_{3} \mathrm{Al}_{2} \mathrm{O}_{12}\right.$, etc.) [3]. In-situ self-healing behavior of defects (such as cracks in the coating) in liquid-Li environments is also an important consideration. These coatings should be formable on various shapes such as the inside of tubes or irregular configurations. The coatings could also improve general corrosion resistance and act as a diffusion barrier for hydrogen isotopes, viz., deuterium and tritium.

\section{EXPERIMENTAL PROCEDURE}

Various experimental methods have been explored to fabricate and characterize insulator coatings for use in liquid- $L i$ environments: (a) oxygen charging of the near-surface region of $\mathrm{V}$-base alloys in $\mathrm{Ar}$ gas $\mathrm{O}<<5 \mathrm{ppm}, \mathrm{H}_{2} \mathrm{O}$ $<5 \mathrm{ppm}$, and total impurity $<20 \mathrm{ppm}$ ) and in air, (b) evaluation of liquid-Li compatibility of the O-charged V-base alloy specimens, (c) reaction of the O-enriched $\mathrm{V}$-base alloy surface with dissolved $\mathrm{Ca}$ in $\mathrm{Li}$ and oxidation of the $\mathrm{Ca}$ $\mathrm{Li}$ layer in high purity $\mathrm{Ar}$ to form the $\mathrm{CaO}$ layer, (d) in-situ electrical resistance measurements of $\mathrm{CaO}$ coatings on $\mathrm{V}-5 \mathrm{Cr}-5 \mathrm{Ti}$ in liquid $\mathrm{Li}$, and (e) characterization of the O-charged specimens and insulator coatings by scanning electron microscopy (SEM) and X-ray diffraction, together with optical examination of the coatings for evidence of surface defects such as spallation or cracks. Thermal cycling tests were also conducted to investigate the integrity of coating layers that formed in-situ. Fabrication of coatings at a relatively low temperature $\left(320-400^{\circ} \mathrm{C}\right)$ has been emphasized.

\section{RESULTS AND DISCUSSION}

Oxygen charging of the surface of $\mathrm{V}-\mathrm{Cr}$-Ti Alloys: Figure 1 shows the thermodynamic stability of solid-state oxide phases, as a function of equilibrium partial pressure of oxygen and temperature, that can form when $\mathrm{V}$-Cr-Ti alloys, $\mathrm{Li}$, and $\mathrm{Ca}$ are exposed to oxygen-containing environments. It is well known that $O$ can be incorporated into the interstitial sublattice in body-centered-cubic (bcc) $\mathrm{V}$ and its alloys. Thus, if $\mathrm{O}$ or $\mathrm{N}$ is present in the alloy (as a reactant), these elements may have a higher affinity for solutes, such as $\mathrm{Ca}, \mathrm{Y}$, or $\mathrm{Mg}$ dissolved in 
$\mathrm{Li}$, than do the alloy elements. In the bcc lattice of $\mathrm{V}-5 \mathrm{Cr}-5 \mathrm{Ti}, \mathrm{O}$ can occupy interstitial sites within the lattice up to several atomic percent. Oxygen charging of $\mathrm{V}-5 \mathrm{Cr}-5 \mathrm{Ti}$ was conducted for up to $48 \mathrm{~h}$ at temperatures between 500 and $1030^{\circ} \mathrm{C}$ in flowing high-purity (99.999\%) $\mathrm{Ar}$ and $\mathrm{N}_{2}$ that contained $\mathrm{O}$ as an impurity. Diffusion coefficients of $\mathrm{O}$ and $\mathrm{N}$ in $\mathrm{V}$ indicate that $\mathrm{O}$ diffuses faster than $\mathrm{N}$ by factors of 10 to 1800 [5]. This property is very important for in-situ formation of CaO. Oxygen charging in an $\mathrm{N}_{2}$ atmosphere lowers the diffusion rate $(\approx 5 \%)$ because of some participation of $N$. Figure 1 shows the weight gain per unit area of the alloy at various temperatures after $17 \mathrm{~h}$ in $\mathrm{N}_{2}$. Based on metallographic information and weight gain, we can control the depth of the O-charged layer by exposure temperature and time in flowing $\mathrm{Ar}$ or $\mathrm{N}_{2}$ atmospheres. Oxygen concentration in the near-surface layer was calculated from the weight gain, surface area, and thickness of the hardened region; it ranged from $250 \mathrm{ppm}$ (as-received) to $\approx 2-3 \%$, depending on position within the layer and exposure conditions.

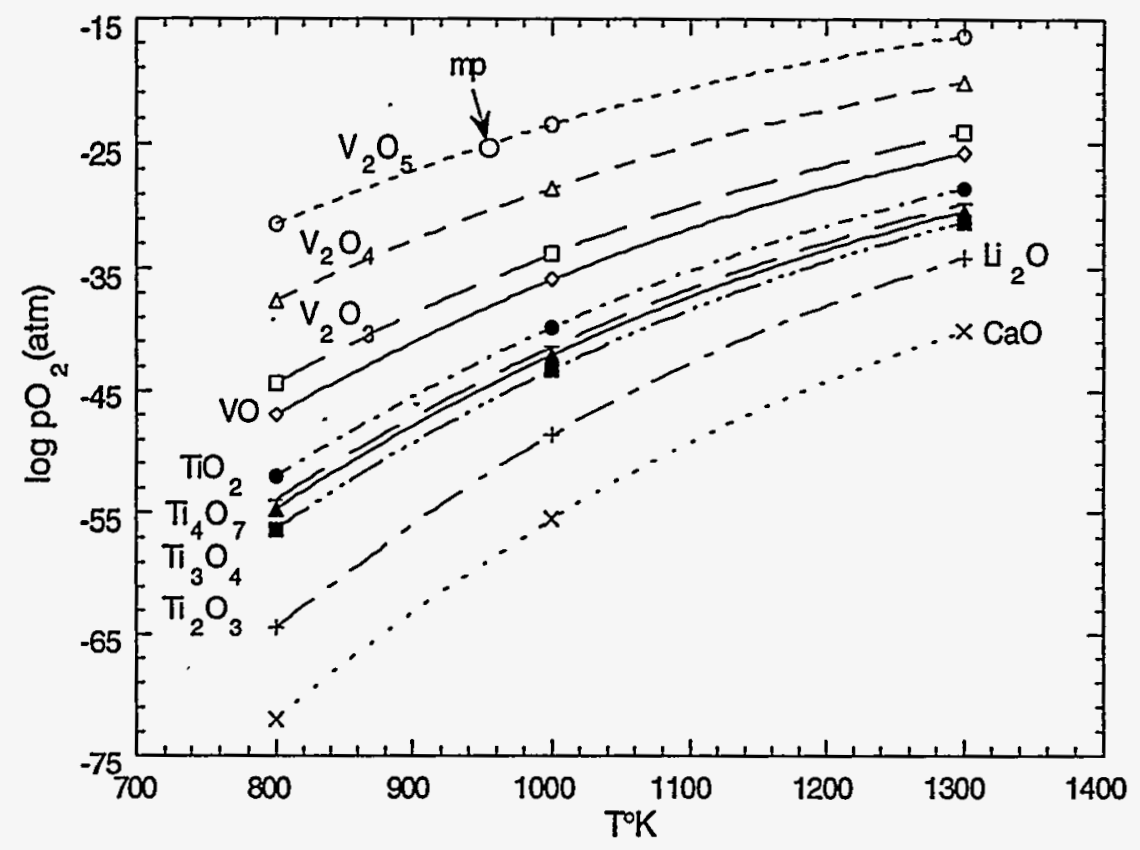

Figure 1. Thermodynamic stability of several possible oxide phases that can form on $\mathrm{V}$-Cr-Ti alloys, $L i$, and $\mathrm{Ca}$ in oxygen-containing environments

Oxygen charging was also performed in air at $400^{\circ} \mathrm{C}$ to avoid melting of $\mathrm{V}_{2} \mathrm{O}_{5}$ $\left(690^{\circ} \mathrm{C}\right.$ ) during oxidation. During oxidation in air at $400^{\circ} \mathrm{C}$ for $20 \mathrm{~h}$, a blue 
amorphous layer $(\approx 1 \mu \mathrm{m}$ thick) formed at the surface. Samples charged with $O$ in high-purity Ar or $\mathrm{N}_{2}$ atmospheres showed the same X-ray spectra before and after $O$ charging. When we measured ohmic resistance (two-point contact) on the surfaces of heat-treated specimens at room temperature, the specimens charged with $\mathrm{O}$ in high-purity $\mathrm{Ar}$ or $\mathrm{N}_{2}$ showed the same ohmic values before and after $\mathrm{O}$ charging. The blue oxide that formed in air at $400^{\circ} \mathrm{C}$ had a resistance of $\approx 5 \Omega$, not very high compared to values for most metal oxides. This oxide is not stable in liquid $\mathrm{Li}$.

Compatibility tests on O-charged V-5Cr-5Ti in liquid Li: Figure 2 shows results of compatibility tests on O-charged samples in flowing liquid $\mathrm{Li}$ at $443^{\circ} \mathrm{C}$ for $298 \mathrm{~h}$. Samples charged with $\mathrm{O}$ at 1030 and $1005^{\circ} \mathrm{C}$ showed the highest weight loss during exposure to liquid $\mathrm{Li}$. Similar results were obtained at $408^{\circ} \mathrm{C}$. In general, specimens that exhibit the greatest weight gain during $O$ charging undergo the greatest weight loss during exposure to $\mathrm{Li}$. Presumably, this indicates that an oxide phase (e.g., $\mathrm{V}_{2} \mathrm{O}_{3}$ ) that formed during $\mathrm{O}$-charging dissolves in liquid $\mathrm{Li}$. However, weight-loss rates for specimens exposed to $\mathrm{Li}$ at 443 and $408^{\circ} \mathrm{C}$ are virtually the same (i.e., $1.68 \mu \mathrm{g} / \mathrm{cm}^{2}-\mathrm{h}$ and $0.84 \mu \mathrm{g} / \mathrm{cm}^{2}-\mathrm{h}$, respectively). In contrast, if weight loss in short-term corrosion tests was controlled primarily by $O$ diffusion in the alloy, the rates would be expected to be relatively independent of the amount of $O$ charged. This would be applicable to any of the thermodynamically stable oxides in the liquid $\mathrm{Li}$; e.g., $\mathrm{BeO}, \mathrm{MgO}, \mathrm{Y}-\mathrm{Al}-$ $\mathrm{O}$ garnet, $\mathrm{Mg}$-Al-O spinel, $\mathrm{Y}_{2} \mathrm{O}_{3}$, and $\mathrm{CaO}$. A similar situation could presumably occur for the formation of nitrides by the reaction of $\mathrm{N}$ in the alloy with metallic elements dissolved in $\mathrm{Li}$. Nevertheless, it is important to determine the optimal condition for O-charging of $\mathrm{V}-5 \mathrm{Cr}-5 \mathrm{Ti}$; O-charging in $99.999 \% \mathrm{Ar}$ at $650^{\circ} \mathrm{C}$ was found to be adequate on the basis of the liquid-Li compatibility tests.

$\mathrm{CaO}$ formation on as-received specimens: In-situ formation of $\mathrm{CaO}$ on asreceived specimens ( $250 \mathrm{ppm} \mathrm{O}$ ) has been investigated in liquid $\mathrm{Li}$ containing $23 \mathrm{wt} . \% \mathrm{Ca}$ at $700^{\circ} \mathrm{C}$ during a 7 -day exposure. We believe the reaction that forms $\mathrm{CaO}$ occurs at the interface between $\mathrm{O}$ at alloy surface and $\mathrm{Ca}$ in the liquid metal. The coating did not completely cover the V-5Cr-5Ti surface, but a high ohmic resistance typical of $\mathrm{CaO}$ (two-point contact of $>20 \mathrm{M} \Omega$ at room temperature) was obtained. 


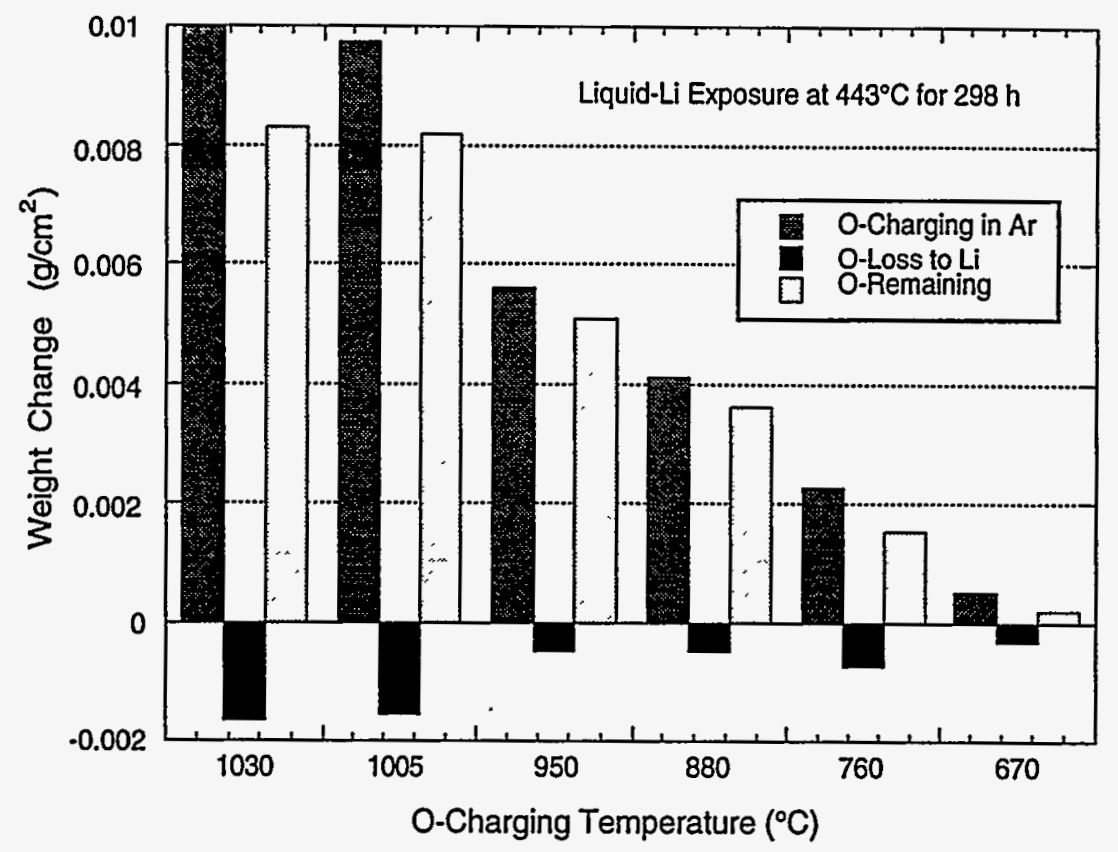

Figure 2. Weight change of $\mathrm{V}-5 \mathrm{Cr}-5 \mathrm{Ti}$ specimens after $\mathrm{O}$ charging in Ar for $40 \mathrm{~h}$ at temperatures between 670 and $1030^{\circ} \mathrm{C}$ and after exposure of $\mathrm{O}$-charged specimens to $\mathrm{Li}$ at $443^{\circ} \mathrm{C}$ for $298 \mathrm{~h}$

$\mathrm{CaO}$ formation on O-charged specimens: To improve formation of $\mathrm{CaO}$ on alloy substrates, O-charged specimens were immersed in Ca-bearing $(0.5-85 \mathrm{wt} . \% \mathrm{Ca})$ liquid $\mathrm{Li}$ for various times and temperatures. This approach was adopted because $O$ in the alloy (as a reactant) may have a higher affinity for a solute such as $\mathrm{Ca}$ dissolved in $\mathrm{Li}$ than for the alloy elements $(\mathrm{V}, \mathrm{Cr}$, and $\mathrm{Ti}$ ). Several experiments were performed to test this hypothesis. Specimens of V-5Cr$5 \mathrm{Ti}$ were heat treated in flowing $\mathrm{Ar}$ at $650^{\circ} \mathrm{C}$ to charge the surface of the alloy with $\mathrm{O}$.

To monitor coating development by measuring electrical resistivity, specimens $(0.25 \times 1.5 \times 0.04$ in.) were attached to Type 304 SS lead wires (1.2 $\mathrm{mm}$ diameter) by electron-beam welding. The specimens were charged with $\mathrm{O}$ in an $\mathrm{Ar}$ atmosphere at $650^{\circ} \mathrm{C}$ for $17-20 \mathrm{~h}$, as described previously. Two specimens were coupled to form one conductivity-measuring unit, as described previously [5]. The specimens were immersed for $17 \mathrm{~h}$ at $400^{\circ} \mathrm{C}$ in a solution of $\mathrm{Li}$ containing $85 \mathrm{wt} . \% \mathrm{Ca}$, which has a liquidus temperature of $\approx 380^{\circ} \mathrm{C}$. Then the specimens were elevated above the liquid and exposed to an $\mathrm{Ar}$ atmosphere 
(which contained $\mathrm{O}$ as an impurity) at $650^{\circ} \mathrm{C}$ for $17 \mathrm{~h}$ to oxidize the $\mathrm{Ca}$, as done in the $O$-charging procedure for the $V$-base alloy. The specimens were immersed in the liquid $\mathrm{Li}-(0.5 \mathrm{wt} . \%) \mathrm{Ca}$ alloy again to measure the electrical resistance of $\mathrm{CaO}$ films at $\approx 400^{\circ} \mathrm{C}$. Figure 3 shows the cell resistance $\left(9.5 \times 10^{5} \Omega\right)$ at a current of $100 \mathrm{nA}\left(10^{-7} \mathrm{~A}\right)$ over a $120-\mathrm{h}$ period at $435^{\circ} \mathrm{C}$. An initial $\mathrm{R}$ value (where $\mathrm{i}=$ current and $\mathrm{R}=$ electrical resistance) was obtained at a current of $1 \mathrm{~mA}$, which was too high and caused polarization of the specimen.

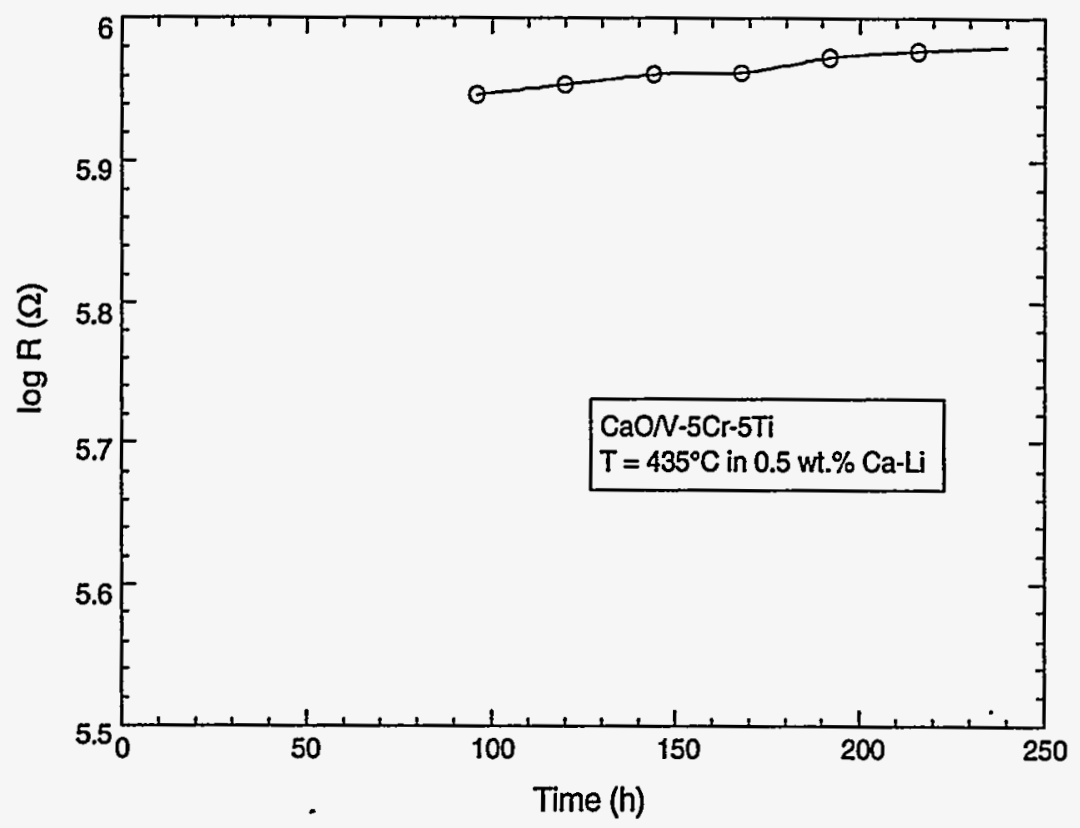

Figure 3. $\log R(\Omega)$ vs. time for CaO coating performed in 0.5 wt.\% Ca-Li environment. CaO coating fabricated by exposure in $85 \mathrm{wt} \% \mathrm{Ca}-\mathrm{Li}$ at $400^{\circ} \mathrm{C}$ and oxidized at $650^{\circ} \mathrm{C}$ for $17 \mathrm{~h}$ in $99.999 \% \mathrm{Ar}$.

Mechanical integrity and self-healing characteristics: Figure 4 shows SEM photomicrographs of the surface of a $\mathrm{CaO}$ coating that contains microcracks. To determine coating thickness, mechanical integrity, and compositional depth profiles in cross section, the specimens were metallographically mounted with an epoxy resin (Fig. 5). As shown in Fig. 5b, depth profiles of the alloy elements near the interface showed that the composition of $\mathrm{Ti}$ and $\mathrm{Cr}$ remains constant and that only a small amount (1-2\%) of the $\mathrm{Ca}$ diffused into the $\mathrm{V}-5 \mathrm{Cr}-5 \mathrm{Ti}$ (1-2 $\mu \mathrm{m}$ depth). From our previous investigation at higher temperatures $\left(\approx 700^{\circ} \mathrm{C}\right)$, 
elemmonlal diffusion was more signilicant and $\geq 10 \% \mathrm{~V}$ was detected in the CaO layer $\mid$ |b|.

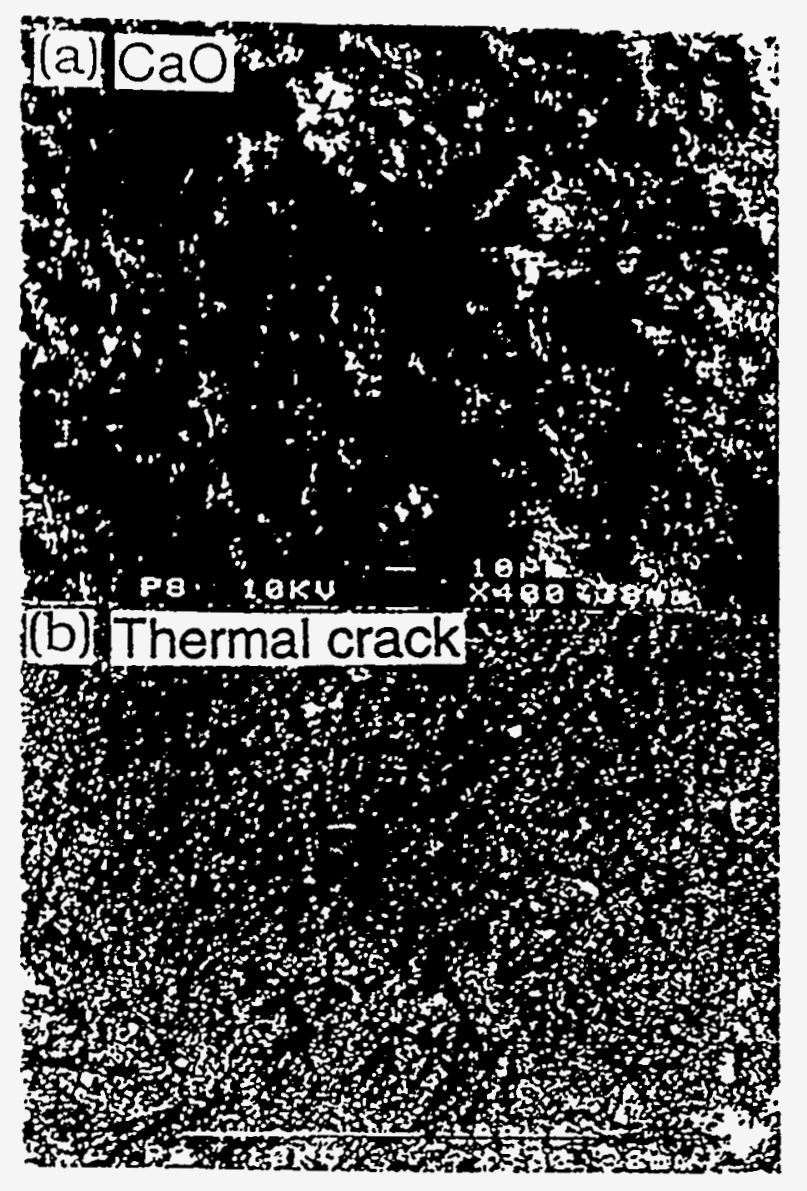

Figure 4. (a) SEM photomicrograph of Figure 5. (a) SEM photomicrograph surface of $\mathrm{CaO}$ coating, and of cross section. and (b) EDS depth (b) microcracks in coating shown in (a) profiles of $\mathrm{V} . \mathrm{Cr}$. Ti, and $\mathrm{Ca}$ at $\mathrm{CaO} / \mathrm{V}-5 \mathrm{Cr}-5 \mathrm{Ti}$ interface of coating formed at $400^{\circ} \mathrm{C}$

With regard to microcracks in the coating layer. $\mathrm{CaO}$ has a higher coefficient of thermal expansion than that of $\mathrm{V}-5 \mathrm{Cr}-5 \mathrm{Ti}\left(12 \times 10^{-6}\right.$ vs. $\left.9.2 \times 10^{-6} / \mathrm{K}\right)$. Therefore. a CaO layer that forms in-situ on a $\mathrm{V}$-alloy will be subjected to a tensile stress during cooling. Based on the photomicrograph shown in Figs. 4 and 5 . $\mathrm{CaO}$ coatings on $\mathrm{V}-5 \mathrm{Cr}-5 \mathrm{Ti}$ have the characteristics described below. The crack pattern consists of regions with diameters of $\approx 30-10 \mu \mathrm{m}$ and crack widths of $\approx 2000$ I over most of the $\mathrm{CaO}$ surface. which suggests that the cracks 
originate by a mismatch of the thermal expansion coefficients during cooling, i.e., they are "crazing cracks." Adhesion of the CaO film to the $\mathrm{V}-5 \mathrm{Cr}-5 \mathrm{Ti}$ substrate appears to be quite good. One approach to minimize microcracking would be to decrease the thickness of the $\mathrm{CaO}$ film to better match its mechanical strength with that of the V-5Cr-5Ti substrate. For example, a $\mathrm{CaO}$ film $\approx 1 \mu \mathrm{m}$ in thickness may have a higher fracture strength and also have a resistance of $\geq 1 \mathrm{M} \Omega$, which is higher than design requirement for fusion reactors by three to four orders of magnitude.

Liu and Smith [7] suggest that no coating may be acceptable because calculated stresses are greater than the tensile flexural strengths of most candidate coatings. Therefore, the coatings are subject to cracking in both tension (e.g., $\mathrm{CaO}$ ) and compression. However, their criteria must be viewed in relationship to the conditions under which the coating is formed (viz., temperature and time), as well as the normal operating temperature. For example, when a $\mathrm{CaO}$ film forms at $400^{\circ} \mathrm{C}$, no stress develops when the coating operates at $400^{\circ} \mathrm{C}$. However, because the fabrication and operating temperatures may differ and the coating will undergo thermal fluctuation during operation, acceptable temperature ranges must be defined to account for these situations. The surface cracks developed during cooling from $400^{\circ} \mathrm{C}$ to room temperature.

Thermally induced strains are usually calculated by assuming linear thermal expansion, namely $\Delta \varepsilon_{\text {thermal }}=\left(\alpha_{\mathrm{CaO}}-\alpha_{\mathrm{V}-5 \mathrm{Cr}-5 \mathrm{Ti}}\right) \times\left(\mathrm{T}_{1}-\mathrm{T}_{2}\right)=\Delta \alpha \times \Delta \mathrm{T} \approx 3 \times 10^{-6} \mathrm{x}$ $375=1.13 \times 10^{-3}$, where $\alpha_{\mathrm{CaO}}$ and $\alpha_{\mathrm{V}-5 \mathrm{Cr}-5 \mathrm{Ti}}$ are the coefficients of thermal expansion of $\mathrm{CaO}$ and $\mathrm{V}-5 \mathrm{Cr}-5 \mathrm{Ti}$, respectively, and $\mathrm{T}_{1}$ and $\mathrm{T}_{2}$ are the upper and lower values of the temperature change. Stresses in the $\mathrm{CaO}$ coating can be relieved by either plastic deformation (including creep), crack formation (microcracking), or spallation. Plastic deformation is possible only when the stress is below the critical stress for the formation of any type of material separation (e.g., cracking). The $\mathrm{CaO}$ layer is subjected to compressive and tensile stress when the temperature is above and below that at which the film formed. When the temperature is cycled slowly, the coating/substrate interface may undergo relaxation such that cracking or spallation does not occur. In any case, because cracking of the $\mathrm{CaO}$ layer during cooling is of the greatest concern, it is important for the coating to exhibit self-healing characteristics in a liquid-metal environment. 
Preliminary studies have been conducted to explore the self-healing properties of $\mathrm{CaO}$ coatings under temperature cycling. Self-healing of $\mathrm{CaO}$ was investigated at temperatures between 300 and $740^{\circ} \mathrm{C}$. At $300^{\circ} \mathrm{C}$, self-healing did not occur in a $10-\mathrm{h}$ period; at $\geq 360^{\circ} \mathrm{C}$, cracks appeared to heal (e.g., at $450^{\circ} \mathrm{C}$, resistivity was restored to its initial value within several hours, and at $500^{\circ} \mathrm{C}$ in $<\mathrm{l}$ h). When a $\mathrm{CaO}$ coating was subjected to compressive stress by increasing the temperature in a similar manner, no appreciable cracking was detected. When temperature was increased to accelerate the healing process, we could not assess whether increases in $\mathrm{iR}$ values were caused by closing of cracks or by diffusion-related healing behavior. Nevertheless, when the system temperature was raised, the rapid response resembled healing of the cracks.

Preliminary work was conducted to explore the self-healing process in terms of diffusion, thermal expansion, and contraction processes within the $\mathrm{CaO}$ layer. In this regard, it is more important to consider reactions that take place at the defect area rather than at the surface region, namely, at the $\mathrm{Li}-\mathrm{Ca} / \mathrm{V}-5 \mathrm{Cr}-5 \mathrm{Ti}(\mathrm{O})$ interface. The $\mathrm{CaO}$ layer growth mechanism could be as follows; initially a thin $\mathrm{CaO}$ forms at the interface by the reaction $\mathrm{Ca}$ (in $\mathrm{Li})+\mathrm{O}$ (in $\mathrm{V}-5 \mathrm{Cr}-5 \mathrm{Ti})=\mathrm{CaO}$ accompanied by inward ambipolar diffusion of $\mathrm{Ca}^{+2}$ ion and electrons. The spontaneous reaction of $\mathrm{Ca}^{+2}+2 \mathrm{e}^{\prime}+\mathrm{O}=\mathrm{CaO}$ will take place at the $\mathrm{CaO} / \mathrm{V}-5 \mathrm{Cr}-$ $5 T i$ interface, including defect areas such as grain boundaries, dislocations, open voids, and microcracks because the diffusivity of $\mathrm{Ca}^{+2}$ is much higher than that of $\mathrm{O}^{-2}$ in $\mathrm{CaO}$ and because growth of the $\mathrm{CaO}$ layer depends on inward diffusion of $\mathrm{Ca}^{+2}$, presumably by a cation vacancy [8] mechanism.

Figure 6 shows the temperature-and-ohm $\mathrm{x}$ area-versus-time response during thermal cycling of a coated specimen in liquid $\mathrm{Li}$. Resistivity of a coated specimen that was cooled to room temperature and then heated to $432^{\circ} \mathrm{C}$ for 50 min stabilized at $\approx 600 \Omega \cdot \mathrm{cm}^{2}$, which is indicative of healing of cracks in the coating. During cooling of the specimen from 430 to $360^{\circ} \mathrm{C}$, the specimen initially exhibited ceramic-type behavior, i.e., ohmic value increased to $\approx 800 \Omega \cdot \mathrm{cm}^{2}$, but during further cooling to $325^{\circ} \mathrm{C}$, the ohmic value decreased precipitously to $\approx 20 \Omega \cdot \mathrm{cm}^{2}$, which is indicative of further crack development. During heating of the specimen to $\approx 450^{\circ} \mathrm{C}$, the ohmic value increased to $\approx 300 \Omega \cdot \mathrm{cm}^{2}$ and stabilized at that value, which is indicative of self-healing of the defects. However, when the temperature increased to $490^{\circ} \mathrm{C}$, the ohmic value dropped immediately because thermal expansion of the liquid caused the meniscus at the liquid/specimen interface to rise and the liquid $\mathrm{Li}$ to wet "new" surfaces of 
O-charged V-5Cr-5Ti. During a $2-\mathrm{h}$ period at $490^{\circ} \mathrm{C}$, the ohmic value increased slowly to the previous value as a $\mathrm{CaO}$ coating formed on this region of the specimen. When the specimen was cooled from 490 to $320^{\circ} \mathrm{C}$, no new cracks developed and the resistivity once again increased, which is indicative of ceramictype behavior. During the next $\approx 100-\mathrm{h}$ period at $320^{\circ} \mathrm{C}$, resistivity increased slowly to $\approx 1200 \Omega \cdot \mathrm{cm}^{2}$. This could be attributed to further repair of the $\mathrm{CaO}$ layer in less protected regions and/or changes in the defect chemistry of $\mathrm{CaO}$ when $\mathrm{Ca}$ was not present at high concentration in liquid Li. Additional work is required to establish the mechanisms for self-healing of $\mathrm{CaO}$ coatings during thermal cycling.

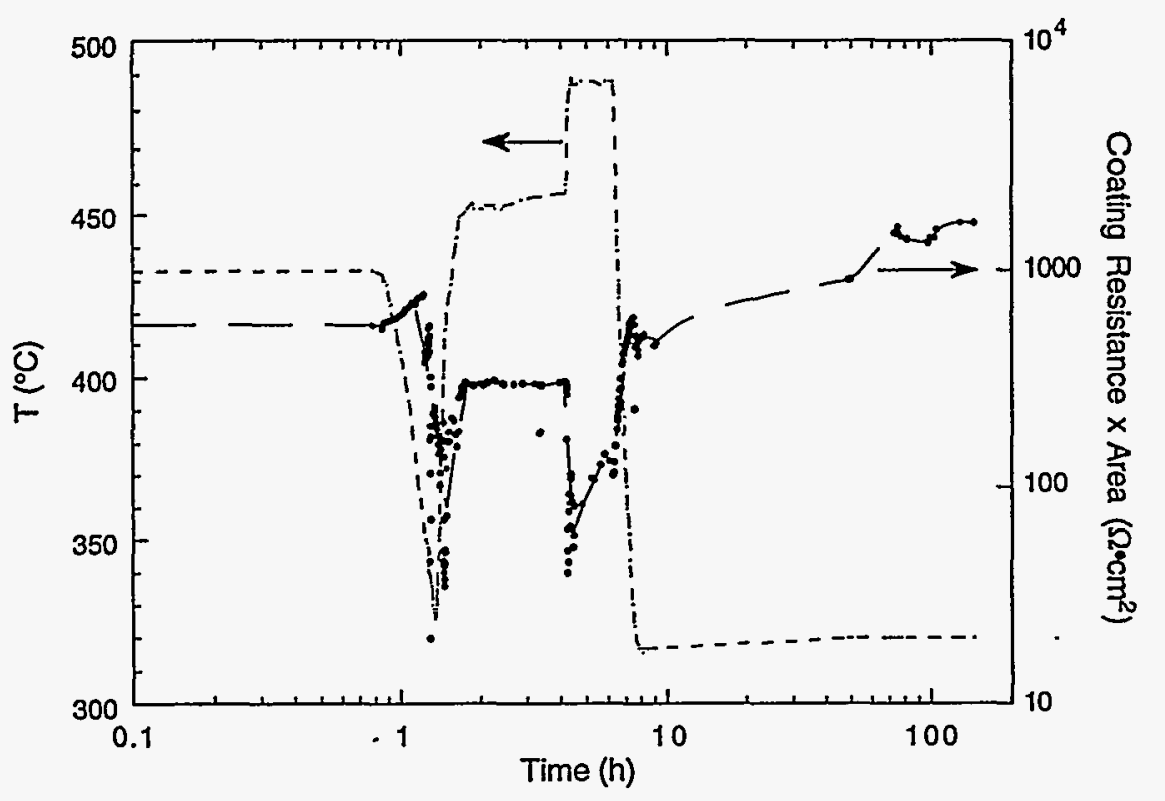

Figure 6. Temperature and ohmic resistance $x$ area $(R \times A)$ vs. time during thermal cycling

\section{CONCLUSIONS}

A method was developed for in-situ fabrication of an electrically insulating $\mathrm{CaO}$ coating on $\mathrm{V}-5 \mathrm{Cr}-5 \mathrm{Ti}$ in a liquid-Li environment. The process involves reaction of an O-enriched alloy surface with liquid $\mathrm{Li}$ containing $\mathrm{Ca}$ at 300$400^{\circ} \mathrm{C}$. Thermal cycling tests were conducted on $\mathrm{CaO}$ coatings that form in-situ on $\mathrm{V}-5 \mathrm{Cr}-5 \mathrm{Ti}$ in liquid $\mathrm{Li}$ containing dissolved $\mathrm{Ca}$ at temperatures between 300 and $740^{\circ} \mathrm{C}$. Microcracks develop in the coating layer during cooling from $>400^{\circ} \mathrm{C}$ to ambient temperature because of the higher expansion coefficient of $\mathrm{CaO}$. After heating, the cracks exhibit self-healing within a $10-\mathrm{h}$ period at $360^{\circ} \mathrm{C}$ and in $<1 \mathrm{~h}$ 
at $500^{\circ} \mathrm{C}$, as evidenced by restoration of the resistivity to its original value. The layer growth and repair mechanism most likely involves the reaction of $\mathrm{Ca}$ (in $\mathrm{Li}$ ) $+\mathrm{O}$ (in $\mathrm{V}-5 \mathrm{Cr}-5 \mathrm{Ti}$ ) to form $\mathrm{CaO}$, accompanied by inward ambipolar diffusion of $\mathrm{Ca}^{+2}$ ion and electrons.

\section{ACKNOWLEDGMENTS}

The authors appreciate interactions with Drs. D. L. Smith, R. Mattas, and C. Reed on applicability of the work to fusion reactor designs. B. Tani of Argonne's Analytical Laboratory provided the X-ray diffraction studies. G. Dragel and R. W. Clark assisted in the experiments.

\section{REFERENCES}

[1] C. C. Baker et al., Tokamak Power System Studies FY 1985, Argonne National Laboratory Report ANL/FPP-85-2 (Dec. 1985).

[2] R. F. Mattas, B. A. Loomis, and D. L. Smith, Vanadium Alloys for Fusion Reactor Applications, JOM, 44(8), 26 (1992).

[3] J.-H. Park, T. Domenico, G. Dragel, and R. W. Clark, Development of Electrical Insulator Coatings for Fusion Power Applications, Fusion Engineering and Design 27, 682-695 (1995).

[4] J.-H. Park and T. F. Kassner, CaO Insulator and Be Intermetallic Coatings on $V$-Base Alloys for Liquid-Lithium Fusion Blanket Applications, Manuscript submitted for 16th IEEE/NPSS Symposium on Fusion Engineering (SOFE '95), Champaign, IL, Sept. 30-Oct. 5, 1995.

[5] J.-H. Park and G. Dragel, Fabrication and Performance Testing of CaO Insulator Coatings on $\mathrm{V}-5 \% \mathrm{Cr}-5 \% \mathrm{Ti}$ in Liquid Lithium, in Fusion Reactor Materials Semiannual Progress Report for the Period Ending September 30, 1994, DOE/ER-0313/17, pp. 231-244 (1994).

[6] J.-H. Park, Intermetallic and Electrical Insulator Coatings on HighTemperature Alloys in Liquid Lithium Environments, Proc. Symp. on HighTemperature Coatings-I, TMS Fall Meeting, Oct. 2-6, 1994, Rosemont, IL.

[7] Y. Y. Liu and D. L. Smith, Ceramic Electrical Insulators for Liquid Metal Blankets, J. Nucl. Mater., 141-143, 38 (1986). 
[8] V. Kumar and Y. P. Gupta, Cation Self-diffusion in Single Crystal CaO, J. Phys. Chem. Solid, 30, 677-685 (1969). 